\title{
Steam-Enhanced Extraction Experiments, Simulations and Field Studies for Dense Non-Aqueous Phase Liquid Removal: A Review
}

\author{
Nor Asni Azizan ${ }^{1, a}$, Samira Albati Kamaruddin ${ }^{2}$ and Shreeshivadasan Chelliapan ${ }^{2}$ \\ ${ }^{1}$ Faculty of Civil Engineering, Universiti Teknologi Malaysia, 81310 Johor Bahru, Malaysia \\ ${ }^{2}$ Department of Engineering, Razak School of Engineering and Advanced Technology, Universiti Teknologi Malaysia \\ Kuala Lumpur, 54100 Kuala Lumpur, Malaysia
}

\begin{abstract}
Experiments, simulations and field studies for dense non-aqueous phase liquid (DNAPL) removal have demonstrated successful recovery through steam-enhanced extraction. Steam-enhanced extraction is an innovative technology for soil and groundwater remediation to remove as much contamination as possible. Most of researchers study the main DNAPL recovery mechanisms such as physical displacement by vaporization, evaporation and condensation, reduction in interfacial tension and DNAPL viscosity influenced by temperature. Other removal mechanism such as steam distillation and steam stripping also has been studied. The removal of DNAPL using steam-enhanced extraction shall be investigated to identify, acquire, analyze, visualize, and evaluate the effectiveness of the remediation. Several parameters can be controlled to justify the successful of the remediation. A comprehensive understanding of the subsurface environment, multiphase fluid flow and the physical processes is required to prevent remediation failure. Thus, it will avoid continuous contamination of the subsurface environment. The researcher can quantify the reduction in contamination remediation and acquire high quality data sets to validate future numerical model. Aim of this paper is to review and to summarize the existing laboratory experiment, simulations and field studies from other researchers regarding steam-enhanced extraction for dense non-aqueous phase liquid removal.
\end{abstract}

\section{Introduction}

Steam-enhanced extraction (SEE) was applied as environmental application from its original developed purpose to enhanced oil recovery. Since 1980s, extensive experiments, simulations and field studies has led to the point which proven the SEE technology can successfully remove the volatile contaminant from unsaturated subsurface [1]. Recently, these studies have been extending the SEE method to recoveries of saturated subsurface with more complex heterogeneity conditions and fractured geologic media. The SEE method involves continuous injection of steam through injection well into subsurface. The steam flows depend mostly to heterogeneity condition of subsurface. Three temperature zones was form which is steam-temperature, variable temperature and ambient temperature. These temperature influence the DNAPL viscosity thus effect the overall process of SEE

\footnotetext{
${ }^{\text {a }}$ Corresponding author : asnie86@yahoo.com
} 
[2-4]. Several processes occur during SEE such as condensation, evaporation and volatilization. This process will continuously occur until it reaches the extraction well [5].

\section{Steam-Enhanced Extraction}

\subsection{Selection of steam-enhanced extraction}

Factors influence the application of steam-enhanced extraction as DNAPL remediation depend on the DNAPL properties such as volatility and viscosity. Volatility of DNAPL can increase the DNAPL saturation from residual saturation. Higher temperature can enhance volatilization thus increase the DNAPL removal rates [6,7]. Viscosity of DNAPL determines the amount of DNAPL saturation displaced by steam front. The steam was capable in mobilizing DNAPL saturation until the ratio of viscosity of DNAPL and water equal to three. If larger, fingering may occur thus reducing the displacement efficiency [8]. Other factors that can influence the application of steam-enhanced extraction as DNAPL remediation is the porous media properties. The porous media types affect the DNAPL removal rate from porous media [9-11]. The DNAPL removal rate is higher in coarser soil than fine soil. The DNAPL removal rate is lower for soil with wider range of grain size due to lower permeability in fine grain. The DNAPL removal rate is the same for variable range of sand size but with longer remediation time as the grain size decrease [12].

The porous media heterogeneity influenced the time of steam move and directly affects cost. Steam movement is drive more towards the permeable layer instead of low permeable layer. The heterogeneity of subsurface in small scale cause fingering at higher flow rates [13]. The layered heterogeneity can cause channeling to occur due to natural beds or manmade such as buried utilities $[14,15]$. Other factors to be considered are DNAPL location and amount of DNAPL. Small amount of DNAPL with location near to ground surface more economical to treat by excavation and incineration. The efficient ways to utilize steam-enhanced extraction is to treat contaminated soil to depth greater than 100 feet [5].

The most effective ways to increase the efficiency of steam-enhanced extraction is to consider the location of injection and extraction well placement and operation. The most effective ways is to surround the contaminated area with 4 to 6 injections well and place the extraction well at center. Thus, the propagation of steam will be balance during steam-enhanced extraction. The distance between each injection well is reported to be between $1.5 \mathrm{~m}$ to $18 \mathrm{~m}$ and made from steel [5].

The efficiency of steam-enhanced extraction also influence by soil permeability. Soil permeability must be sufficient to allow steam heat. The injection rate is depending on pressure. The pressure must be not more than soil fracture pressure of 1.65 pounds per square inch per meter of depth to avoid overburden pressure [16]. Low soil permeability with low injection rate will increase time of heat lost to overburden and underburden thus is ineffective. Injection pressure influences the steam injection rate as well as temperature and steam quality. Increase temperature does not increase the heating rate. It is because the increase temperature will cause increase of heat loss. The steam generation will be slow causes longer recovery time [17]. Steam quality is the total water proportion in vapor phase. 100 $\%$ steam quality is when no liquid water present. Steam quality influence the ratio of oil and steam at extraction well $[18,19]$.

\subsection{Recent research using steam-enhanced extraction}

Recent laboratory, numerical simulation studies and field studies have contribute major affect in remediation of DNAPL on contaminated sites. From laboratory and numerical simulation studies, researcher can study and investigate how steam and air act and react to remediate DNAPL. Laboratory and numerical simulation can provide accurate data sets to study DNAPL remediation issues due to possible conduct of controlled experiment and model under know condition of porous media heterogeneity. The summary of recent research using steam-enhanced extraction is shown in Table 1. 
Table 1. Recent research of DNAPL remediation through steam-enhanced extraction technology or thermal remediation from 2011 to 2015.

\begin{tabular}{|c|c|c|c|c|c|c|}
\hline $\begin{array}{c}\text { Research } \\
\text { Type }\end{array}$ & Size & DNAPL & $\begin{array}{c}\text { Remediation } \\
\text { Method }\end{array}$ & Research Issue & $\begin{array}{c}\text { Media/ } \\
\text { Condition }\end{array}$ & Ref. \\
\hline $\begin{array}{c}\text { Field } \\
\text { demonstration }\end{array}$ & $\begin{array}{c}1210 \mathrm{~m}^{2} \\
\text { with } 14 \mathrm{~m} \text { to } \\
50 \mathrm{~m} \text { depth }\end{array}$ & $\begin{array}{l}\text { PCE, } \\
\text { TCE, } \\
1,1,1,1- \\
\text { TCA }\end{array}$ & $\begin{array}{l}\text { Steam-enhanced } \\
\text { extraction and } \\
\text { soil vapor } \\
\text { extraction }\end{array}$ & $\begin{array}{l}\text { Savannah River } \\
\text { serious } \\
\text { contamination } \\
\text { problem }\end{array}$ & $\begin{array}{c}\text { Heterogeneous } \\
\text { Saturated / } \\
\text { Unsaturated }\end{array}$ & [20] \\
\hline $\begin{array}{l}\text { Experiment } \\
\text { 2-D } \\
\text { Simulation } \\
\text { T2VOC }\end{array}$ & $\begin{array}{c}40 \mathrm{~cm} \\
\text { height, } \\
50 \mathrm{~cm} \text { width, } \\
5 \mathrm{~cm} \\
\text { thickness }\end{array}$ & TCE & $\begin{array}{l}\text { Steam-enhanced } \\
\text { extraction } \\
\text { injection and air } \\
\text { injection }\end{array}$ & $\begin{array}{l}\text { TCE removal in } \\
\text { variable porous } \\
\text { media }\end{array}$ & $\begin{array}{l}\text { Heterogeneous / } \\
\text { Homogeneous } \\
\text { Saturated / } \\
\text { Unsaturated }\end{array}$ & [21] \\
\hline $\begin{array}{c}\text { Simulation } \\
\text { 3-D TMVOC }\end{array}$ & $\begin{array}{c}109 \mathrm{~m} \\
\text { height, } \\
204 \mathrm{~m} \text { width, } \\
218 \mathrm{~m} \text { length }\end{array}$ & TCE & Thermal* & $\begin{array}{l}\text { TCE removal in } \\
\text { fractured geologic }\end{array}$ & $\begin{array}{l}\text { Fractured } \\
\text { Geologic }\end{array}$ & [22] \\
\hline $\begin{array}{l}\text { Simulation 3- } \\
\text { D TMVOC }\end{array}$ & $\begin{array}{l}20 \mathrm{~m} \text { depth, } \\
8 \mathrm{~m} \text { radius }\end{array}$ & $\begin{array}{l}1,2- \\
\text { DCA }\end{array}$ & Thermal* & $\begin{array}{l}\text { 1,2-DCA removal } \\
\text { in fractured } \\
\text { geologic }\end{array}$ & $\begin{array}{l}\text { Fractured } \\
\text { Geologic }\end{array}$ & [23] \\
\hline $\begin{array}{l}\text { Simulation } \\
\text { 3-D } \\
\text { TMVOC }\end{array}$ & $\begin{array}{l}27.7 \mathrm{~m} \\
\text { depth, } 1.5 \mathrm{~m} \\
\text { radius }\end{array}$ & TCE & Thermal* & $\begin{array}{l}\text { TCE removal in } \\
\text { fractured geologic } \\
\text { at jet engine } \\
\text { testing facilities }\end{array}$ & $\begin{array}{l}\text { Fracture } \\
\text { Geologic }\end{array}$ & [24] \\
\hline $\begin{array}{l}\text { Experiment } \\
\text { 2-D }\end{array}$ & $\begin{array}{c}40 \mathrm{~cm} \\
\text { height, } \\
50 \mathrm{~cm} \text { width, } \\
5 \mathrm{~cm} \\
\text { thickness }\end{array}$ & TCE & $\begin{array}{c}\text { Steam-enhanced } \\
\text { extraction }\end{array}$ & $\begin{array}{l}\text { TCE removal in } \\
\text { variable } \\
\text { heterogeneous } \\
\text { media }\end{array}$ & $\begin{array}{c}\text { Heterogeneous } \\
\text { Unsaturated }\end{array}$ & [25] \\
\hline $\begin{array}{c}\text { Field } \\
\text { demonstration } \\
\text { Experiment } \\
\text { Mathematical }\end{array}$ & $\begin{array}{c}15.2 \mathrm{~m} \\
\text { depth, } \\
\text { volume of } \\
696 \mathrm{~m}^{3}\end{array}$ & $\begin{array}{l}\text { TCE, } \\
\text { DCE } \\
\text { and VC }\end{array}$ & Thermal* & $\begin{array}{l}\text { TCE, DCE and } \\
\text { VC in variable } \\
\text { fractured geologic }\end{array}$ & $\begin{array}{l}\text { Fracture } \\
\text { Geologic }\end{array}$ & [26] \\
\hline $\begin{array}{c}\text { Field } \\
\text { demonstration }\end{array}$ & $\begin{array}{l}6.2 \mathrm{~m} \text { depth, } \\
\text { volume } \\
5097 \mathrm{~m}^{3}\end{array}$ & PCE & Thermal* & $\begin{array}{l}\text { PCE removal } \\
\text { from tight clays }\end{array}$ & $\begin{array}{c}\text { Homogeneous } \\
\text { Saturated }\end{array}$ & [27] \\
\hline $\begin{array}{l}\text { Experiment } \\
1-D\end{array}$ & $\begin{array}{c}0.3 \mathrm{~m} \text { depth, } \\
5 \mathrm{~cm} \\
\text { diameter }\end{array}$ & $\begin{array}{l}1,2- \\
\text { DCA }\end{array}$ & Thermal* & $\begin{array}{c}\text { 1,2-DCA removal } \\
\text { characterization } \\
\text { from fractured } \\
\text { clay }\end{array}$ & $\begin{array}{c}\text { Homogeneous } \\
\text { Saturated }\end{array}$ & [28] \\
\hline $\begin{array}{l}\text { Experiment } \\
2-\mathrm{D}\end{array}$ & $\begin{array}{l}38.1 \mathrm{~cm} \\
\text { height, } \\
13.97 \mathrm{~cm} \\
\text { width, } \\
73.66 \mathrm{~cm} \\
\text { length }\end{array}$ & TCE & Thermal* & $\begin{array}{l}\text { Observation of } \\
\text { trapped gas during } \\
\text { TCE removal }\end{array}$ & $\begin{array}{c}\text { Heterogeneous } \\
\text { Saturated }\end{array}$ & [29] \\
\hline
\end{tabular}

*Thermal means in situ thermal remediation either being stated as other than steam-enhanced extraction or no specific method stated. 
From 1952 to 1978, multiple volatile organic compound (VOC) such as TCE, PCE and 1,1,1-TCA (1,1,1-Trichloroethane) has been identified causing the Savannah River in serious contamination problem. Total amount of 400,000 pounds VOC was successfully removed to date and $75 \%$ removed within first 18 month [20]. Peng, et al. [21] investigate the TCE remediation using co-injection of steam and air in unsaturated heterogeneous porous media and further research to saturated homogenous porous media. The results show that higher removal rate for coarse sand compared to fine sand. Chen, et al. [22] has study TCE removal in 3-D fractured geologic media using thermal remediation. The study was aim to investigate the heat transfer behavior and evaluate the sensitivity of parameter through numerical simulation using TMVOC TOUGH2 program. The results show that the TCE removal rate influence by matrix permeability and encouraged by increased fracture density.

Chen, et al. [23] has research the removal of 1,2-DCA (1,2-Dichloroethane) from fractured geologic media of sandstone using thermal remediation. The results shows that more than $99 \% 1,2-$ DCA are successfully removed. McKenzie [24] has investigate the remediation of TCE in fractured geologic media using thermal conductive heating at jet engine testing facilities of Naval Air Warfare Center (NAWC) in West Trenton, New Jersey. The results from numerical simulation shows 67\% TCE was successfully removed compared to $63.5 \%$ TCE removal reported on site. The heterogeneity effect of porous media on TCE removal using steam-enhanced extraction (SEE) was studied by Wang, et al. [25]. The results show that the TCE removal percentage for three experiments is $89.5 \%, 88.2 \%$ and $85.2 \%$.

Rodriguez [26] research the thermal heating application to removed chlorinated solvents such TCE, cis-1,2-dichloroethylene (DCE) and vinyl chloride (VC) from fractured geologic. The results show that the distance between point of compliance and upgradient domain face influence pore water concentration of fracture rock. The PCE remediation using in situ thermal desorption has been investigated by Heron, et al. [27] on site at San Francisco, California. After 110 days of heating, $2540 \mathrm{~kg}$ of PCE was successfully recovered. Liu, et al. [28] investigate the chlorinated volatile organic compound removal characteristic from fractured clay using boiling. The results reverses the multiphase flow code predictions which state that pressure will increase when heating low permeable material, leading to overturn the boiling. The trapped gas behavior under passive venting conditions was investigate by Martin and Kueper [29] during application of electrical resistance heating in removal of TCE. The results show the influence of gas phase venting during remediation process of electrical resistance heating.

\section{Discussions}

The physical displacement is the main important removal mechanism for DNAPL remediation involves volatilization, evaporation, steam distillation and steam stripping [8]. The physical displacement is influenced by steam boiling point. Contaminants with low boiling point than water show greater recoveries [30-34]. The steam temperature, variable temperature and ambient temperature plays an important factor in the performance of SEE [14, 18, 35]. These temperature also influence the oil residual saturation [2-4] vapor pressure and interfacial effects [7]. Heterogeneity of subsurface shows greater impact on DNAPL recoveries rate. The DNAPL removal rate is higher in coarse sand compared to fine sand $[21,25]$. In fractured geologic media, the DNAPL removal rate is influence by matrix permeability and fracture density [22]. In addition, the distance between point of compliance and upgradient domain face directly affect the pore water concentration of fracture geologic media which consequently affect the DNAPL removal [26]. The DNAPL removal can be accelerated from low permeability clay and occur when half or less pore water are recovered [28]. The SEE application shows successful application in DNAPL remediation [23, 24, 27].

\section{Conclusions}

Steam-enhanced extraction has shown greatest impact to DNAPL removal from saturated/unsaturated subsurface with complex heterogeneity and fractured geologic media. More subsurface 
characterization effort is required and comparison to other technology with the same condition shall be made in terms of performance, cost and remediation time. More experiments, simulations and field studies shall be performed to develop advanced steam-enhanced extraction technology to ensure continuance of environmental quality protection.

\section{Acknowledgements}

This work was supported by of the Ministry of Education Malaysia and sponsor by Universiti Teknologi Malaysia (UTM). The sponsorship is through TIER 2 Encouragement Grant UTM with cost center number of Q.K130000.2640.10J93.

\section{References}

[1] E.L. Davis, Steam injection for soil and aquifer remediation, Environmental Protection Agency, United States, (1998).

[2] T.A. Edmondson, Effect of temperature on water flooding, J. of Canadian Petroleum Technology, 4, 236-242, (1965).

[3] S.W. Poston, S. Ysrael, A. Hossain and E.F. Montgomery III, The effect of temperature on irreducible water saturation and relative permeability of unconsolidated sands, Society of Petroleum Engineers, 10,171-180, (1970).

[4] E.L. Davis and B.K. Lien, Laboratory study on the use of hot water to recover light oily wastes from sands, Environmental Protection Agency, United States, (1993).

[5] Engineering Forum Issue Paper, In situ treatment technologies for contaminated soil, Environmental Protection Agency, United States, (2006).

[6] K. Udell and L. Stewart, Combined steam injection and vacuum extraction for aquifer cleanup, Proc. of the Int. Conf. on Subsurface Contamination by Immiscible Fluids, Calgary, (1990).

[7] S. Lingineni and V.K. Dhir, An experimental and theoretical study of remediation of multicomponent organic contaminants in the unsaturated soil by venting, ASME-HTD, 193, 9999, (1992).

[8] L.D. Stewart and K.S. Udell, Mechanisms of residual oil displacement by steam injection, SPE Reservoir Engineering, 3, 233-1,242, (1988).

[9] P.R de Percin, Demonstration of in situ steam and hot-air stripping technology, J. of the Air and Waste Management Association, 41(6), 873-877, (1991).

[10]J.S. Lighty, G.D. Silcox, D.W. Pershing, V.A. Cundy and D.G. Linz, Fundamentals for the thermal remediation of contaminated soils, Particle and bed desorption models, Environmental Science and Technology, 24, 750-757, (1990).

[11]L. Tognotti, M. Flytzani-Stephanopoulos, A.F. Sarofim, H. Kopsinis and M. Stoukides, Study of adsorption-desorption of contaminants on single soil particles using the electrodynamic thermogravimetric analyzer, Environmental Science and Technology, 25, 104-109, (1991).

[12]A. Hadim, F. Shah and G. Korfiatis, Laboratory studies of steam stripping of LNAPLcontaminated soils, Soil and Sediment Contamination, 2, 37-58, (1993).

[13]M.D. Basel and K.S. Udell, Two-dimensional study of steam injection into porous media, Multiphase Transport in Porous Media, ASME-HTD, 127, 39-46, (1989).

$[14] \mathrm{K}$. Cook, In situ steam enhanced recovery process, Environmental Protection Agency, United States, (1995).

[15]M.D. Basel and K.S. Udell, Effect of heterogeneities on the shape of condensation fronts in porous media, Heat Transfer in Geophysical Media, ASME HTD, 172, 63-70, (1991).

[16]K.S. Udell, M. Itamura, L. Alvarez-Cohen and M. Hernandez, NAS Lemoore JP-5 cleanup demonstration, Berkeley Environmental Restoration Center, University of California, Berkeley, (1994).

[17]F.S. Johnson, C.J. Walker and A.F. Bayazeed, Oil Vaporization During Steamflooding, Society of Petroleum Engineers, Dallas, (1968). 
[18]N.A. Myhill and G.L. Stegemeier, Steam-drive correlation and prediction, J. of Petroleum Technology, 30(2), 173-182, (1978).

[19]A.K. Singhal, Physical model study of inverted seven-spot steamfloods in a pool containing conventional heavy oil, J. of Canadian Petroleum Technology, 19, 12-124, (1980).

[20]B. Kramer, J. Kupar, J. Ross, J. Cardoso-Neto, D.G. Jackson and B.B. Looney, Concluding a steam injection remediation project at a DNAPL Source Zone at the Savannah River Site, Waste Management Symposia, Arizona, (2015).

[21]S. Peng, N. Wang and J. Chen, Steam and air co-injection in removing residual TCE in unsaturated layered sandy porous media, J. of Contaminant Hydrology, 153, 24-36, (2013).

[22]F. Chen, R.W. Falta and L.C. Murdoch, Numerical analysis of thermal remediation in 3D fieldscale fractured geologic media, Groundwater, 53(4), 572-587, (2014).

[23]F. Chen, R.W. Falta and L.C. Murdoch, Numerical analysis of contaminant removal from fractured rock during boiling, J. of Contaminant Hydrology, 134-135, 12-21, (2012).

[24]A. McKenzie, Simulating remediation of trichloroethylene in fractured bedrock by thermal conductive heating using the numerical model TMVOC, Master Thesis, Queen's University, Canada, (2013).

[25]N. Wang, S. Peng and J. Chen, 2D-box study on effects of media heterogeneity on remediation of TCE by steam enhanced extraction, Advances in Environmental Protection, 3, 45, (2013).

[26]D. Rodriguez, Assessment of thermal heating for the removal of chlorinated solvents from fractured bedrock, PhD Thesis, Queen's University, Canada, (2012).

[27]G. Heron, J. Lachance and R. Baker, Removal of PCE DNAPL from tight clays using in situ thermal desorption, Groundwater Monitoring and Remediation, 33, 31-43, (2013).

[28]X. Liu, L.C. Murdoch, R.W. Falta and T. Tan, Experimental characterization of CVOC removal from fractured clay during boiling, Int. J. of Heat and Mass Transfer, 70, 764-778, (2014).

[29]E.J. Martin and B.H. Kueper, Observation of trapped gas during electrical resistance heating of trichloroethylene under passive venting conditions, J. of Contaminant Hydrology, 126, 291-300, (2011).

[30] J.R. Hunt, N. Sitar and K.S. Udell, Nonaqueous phase liquid transport and cleanup: 1. analysis of mechanisms, Water Resources Research, 24, 1247-1258, (1988).

[31]P.W. Atkins, Physical Chemistry, Oxford University Press, (1998).

[32] G. Heron, S. Carroll and S.G. Nielsen, Full-scale removal of DNAPL constituents using steamenhanced extraction and electrical resistance heating, Groundwater Monitoring and Remediation, 25, 92-107, 2005.

[33]G. Heron, K. Parker, J. Galligan and T.C. Holmes, Thermal treatment of eight CVOC source zones to near nondetect concentrations, Groundwater Monitoring and Remediation, 29, 56-65, (2009).

[34]K.S. Udell, Application of in situ thermal remediation technologies for DNAPL removal, International Association of Hydrological Sciences, (1998).

[35]P.E. Baker, An experimental study of heat flow in steam flooding, Society of Petroleum Engineers J., 9, 89-99, (1969). 